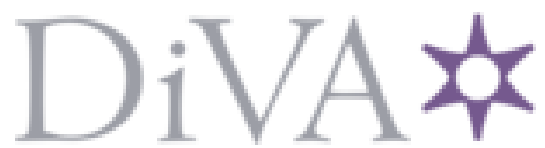

http://www.diva-portal.org

This is the published version of a chapter published in Visions of North in premodern Europe.

Citation for the original published chapter:

Wangefelt Ström, H., Barbierato, F. (2018)

Omne malum ab Aquilone: images of the evil North in early modern Italy and their impact on cross-religious encounters

In: Dolly Jørgensen and Virginia Langum (ed.), Visions of North in premodern Europe (pp. 265-286). Turnhout: Brepols

Cursor Mundi

https://doi.org/10.1484/M.CURSOR-EB.5.114066

N.B. When citing this work, cite the original published chapter.

Permanent link to this version:

http://urn.kb.se/resolve?urn=urn:nbn:se:umu:diva-147655 


\title{
OMNE MALUM AB AQUILONE: IMAGES OF THE EVIL NORTH IN EARLY MODERN ITALY AND THEIR IMPACT ON CROSS-RELIGIOUS ENCOUNTERS
}

\author{
Helena Wangefelt Ström and Federico Barbierato
}

Out of the north the evil will break forth on all the inhabitants of the land. (Jeremiah 1. 14)

For disaster looms out of the north, even terrible destruction. (Jeremiah 6.1)

Betwixt two charming words, comes in my father, And like the tyrannous breathing of the north. Shakes all our buds from growing.

(William Shakespeare, Cymbeline, I.iv.35-37.1)

$\mathrm{T}$

yrannous, destructive, infertile, intellectually inferior, and the home of witches and werewolves. A northern visitor to southern Europe in imbued with forceful associations related to the North that were well established, historically rooted, and alive in the minds of the people in the South. These concepts, mythological images, and archetypes were well known also by the northerners themselves, and were, contrary to what one might expect, not merely a yoke of negative expectations but also in some cases cleverly used to enhance certain aspects of a constructed image or a desired reputation.

Helena Wangefelt Ström is a PhD student in the Department of Culture and Media Studies at Umeå University, where she is writing a dissertation on the heritage production process of religion and sacredness.

Federico Barbierato is a social and cultural historian at the University of Verona who has studied religious dissent, unbelief, and censorship. 


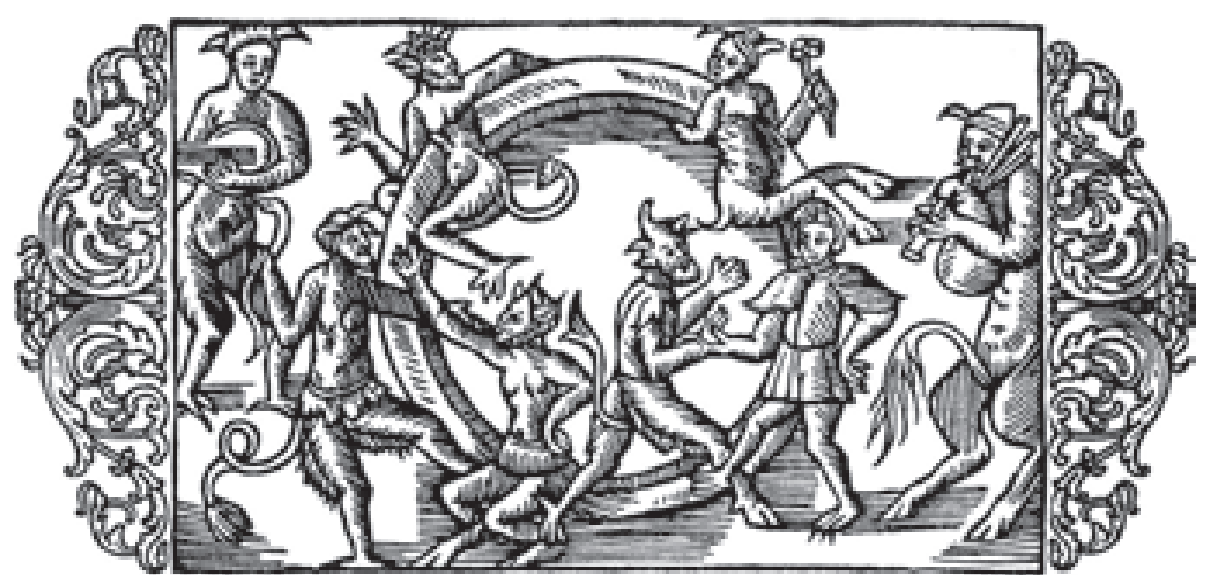

Figure 13.1: Minor devils, demons, satyrs, and hobgoblins. Detail from Olaus Magnus, Historia de gentibus septentrionalibus, Rome. 1555. Image in public domain. ${ }^{1}$

From where does the notion of the North as the origin of evil derive? And, from a practical point of view, how did this presumption affect the way in which foreigners and phenomena coming from or associated with the North were perceived in encounters with people in the South? What values were linked to northernness, and how were they used? With this chapter, we want to introduce a discussion concerning the impacts of the popular, academic, and theological notions of the 'evil' North on actions and encounters between South and North, in particular in the field of religion. Starting from the origins of the image of the evil North in history and religion, we will move on to explore some of its representations in literature and iconography. We will then examine perceptions of the North as held in the early modern South, and how such images were instrumentalized for multiple purposes: during the Reformation as anti-Lutheran or anti-Catholic, and during the Swedish imperial era to intimidate or motivate adversaries and allies. Before concluding, we dwell a moment on the uses of the North and its evil nature employed by Queen Christina of Sweden during and after her conversion to Catholicism and her move to Rome. Although the confines of space allow us to assess only a very narrow selection of sources and examples, our overall aim is to point out and suggest further extensive explorations of the multiple uses of the ascribed evilness of the North, in particular in the field of religious and cultural controversies. ${ }^{1}$

${ }^{1}$ For an introduction to the work, see <http://tridente.it/venetie/fhome.htm> [accessed 1 May 2016]. 


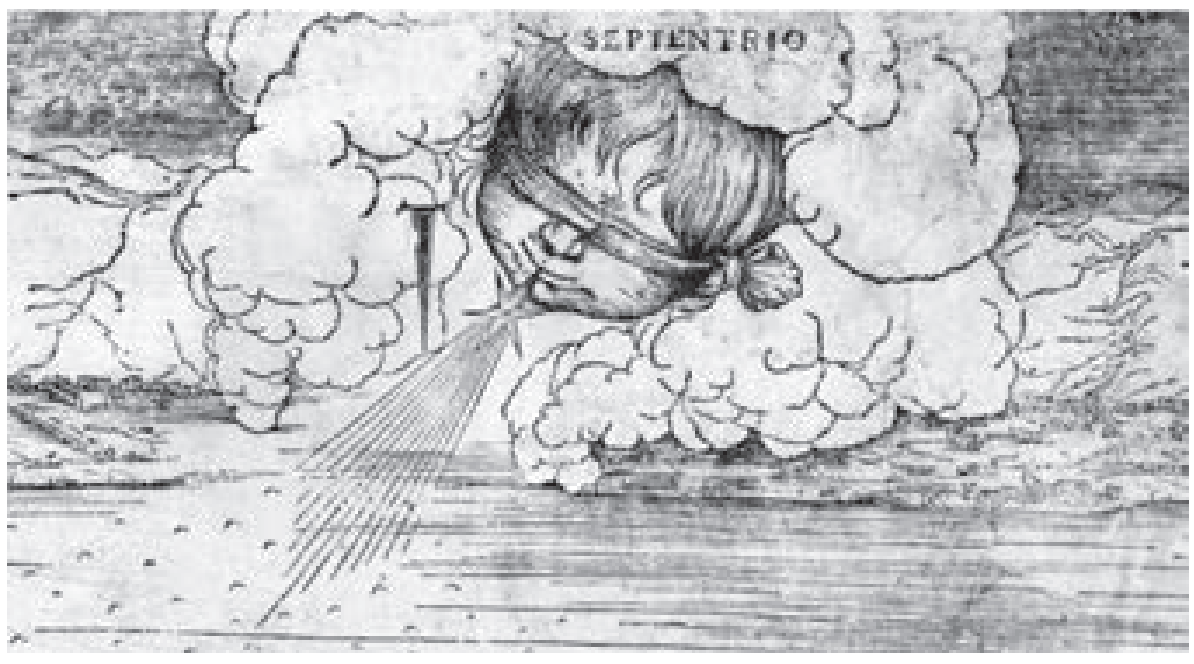

Figure 13.2: The Northern Wind, Septentrio. Detail from Jacopo de Barbari, Map of Venice,

Venice, Museo Correr. 1501. Digital version released into public domain by Museo Correr.

The notion of northern evil is known through history and across cultures, and it appears under many appearances and names: Aquilone, Septentrione, Boreas, Tramontana, Bise, Mistral. ${ }^{2}$ The image of the North as a bringer of evil and destruction, or, indeed, as a place of evil in itself, is supported by numerous verses in the Bible and occurs also in other religions, throughout history, and in a multitude of expressions and cultures. ${ }^{3}$ Within the northern countries, the Sami were part of the mysterious North and were connected to magical powers and exotic appearances. In an early modern context in which Northern Europe was intimately connected to the profound changes following the Reformation, and in which Sweden was building an image of a successful great power as the land of the Lion of the North, the Athens of the North, and the Polar Star, a narrative of northern evil and danger was nonetheless still alive and widespread.

The North Wind was commonly feared as a destructive force that could spoil harvests and cause medical problems. ${ }^{4}$ This might be one reason why, in

${ }^{2}$ For a broader picture of the concept, see for example Beller and Leerssen, Imagology, or, in the same series, Fjaggesund, The Dream of the North.

${ }^{3}$ See, for example, Auger's essay on myths and notions regarding the Vikings in this volume.

${ }^{4}$ The question was debated. See, for example, the discussion in Zacchia, Quaestiones medico legales, qui continetur consilia et responsa, III, 186-87. The observations of Alessandro Petronio are interesting, in Delli Romani et di conservar la sanità, pp. 10, 13, 20, 31-32, 163, 303, 406 and, most of all, Cartegni, Trattato de venti in quanto si appartiene al medico, pp, 17, 33, 38-43. 
Jacopo de Barbari's map of Venice (1501), the North Wind is the only one of the personalized putti head winds that is blindfolded (Figure 13.2). Blindfoldedness in early modern Europe could, as Adriano Prosperi has pointed out, be connected to both positive and negative qualities and associations, including, for example, the blindfolded and fair; blinded by the crowds; Justice as blindfolded; the blindfolded and mislead Synagogue; or the blindfolded jester symbolizing stupidity and human flaws. In this case, the North Italian tradition of the North Wind as bringer of diseases and spoiler of harvests makes it plausible that the point of the representation is to show a pre-Reformation lack of enlightenment, manners, and civilization. ${ }^{5}$

The images of the North are a beloved topos in early modern literature. George Granville, The Lord Lansdowne, described the North Wind as the raging and destructive force in his dramatic poem The British Enchanters: Or, No Magic Like Love (1701):

\author{
When Love's away then Discord reigns \\ The Furies he unchains \\ Bids Aeolus unbind \\ The Northern Wind, \\ That fetter'd lay in Caves, \\ And root up Trees, and plough the Plain, \\ Old Ocean frets and raves, \\ From their deep Roots the Rocks he tears, \\ Whole Deluges he lets fly, \\ That dash against the Sky, \\ And seem to drown the Stars, \\ Th'assaulted Clouds return the Shock \\ Blue Lightnings singe the Waves, \\ And Thunder rends the Rock. ${ }^{6}$
}

In William Shakespeare's play KingJohn, the North Wind represents the cold:

And none of you will bid the winter come

To thrust his icy fingers in my maw,

Nor let my kingdom's rivers take their course

Through my burned bosom, nor entreat the north

To make his bleak winds kiss my parched lips

And comfort me with cold?

${ }^{5}$ Prosperi, Giustizia bendata, pp. 34-36.

${ }^{6}$ Lord Lansdowne, 'Ode to Discord' in The British Enchanters: Or, No Magic Like Love, Act II, Scene I, pp. 267-68.

${ }^{7}$ Shakespeare, King John, v.vii. 36-41. 
In Othello, however, the North is an image of liberty and freedom, and of something impossible to control:

'Twill out, 'twill out. I peace?

No, I will speak as liberal as the north;

Let heaven, and men, and devils, let them all,

All, all cry shame against me, yet I'll speak. ${ }^{8}$

The idea of North as strong and free is reflected in other writings as well. Cesare Ripa in his Iconologia (1603) describes the North as Septentrione. ${ }^{9}$ Ripa's North is an older man, proud looking, tall, and muscular. He is a virile man, robust and 'full of meat'. Ripa says that the North is generally depicted as having fair complexion, blonde hair, cerulean blue eyes, and wearing white armour, with one hand always ready to draw his sword. All of these physical assets are explained by the cold northern climate supposedly giving people a better stomach and improving their digestion. Septentrione is also war loving and insensitive to pain and death - the latter statement referring to Petrarch:

Nemica naturalmente di pace,

Nasce una gente à cui il morir non dole. ${ }^{10}$

(Natural enemy to peace,

A people is born to which death does not hurt).

Uniting these different aspects and perceptions of the evil and untameable North is the southern viewpoint. Referring to a place as physically being in an entirely different or opposite direction than the subject reinforces the otherness; the place is defined in the eyes of the other, and made 'Other' and different. In the case of the North, that defining spectator is often southern Europe. As Matti Klinge points out,

To speak of a part of the world as being north, south, east, or west, implies of course a relation to some other part. In the Nordic world, that relation is primarily to continental Europe. It is in relation to Europe that the North sees itself as poor and peripheral, and often as young and parvenu. ${ }^{11}$

8 Shakespeare, Othello, v.ii. 217-220.

9 Ripa, Iconologia, pp. 497-98.

${ }^{10}$ Francesco Petrarca, Canzoniere, Poem 28, 11. 50-51.

11 Klinge, 'Aspects of the Nordic Self', p. 260. 
The North was thus always relational and, as such, set the parameters for descriptions and images of encounters between North and South. These images, as we shall see, could be used equally both for and against the North and its inhabitants.

\section{Early Modern Images of the North: Inferior Intellects in the Cold}

From the Italian point of view, the notion of the North, or Septentrione, was extremely complex, and it varied substantially over time. First of all, the concept of the North was vast in Italy and indicated not a geographical North, but rather an anthropological and religious North. The North coincided with the Ultramontanes, all the different peoples living on the other side of the Alps. No clear cultural or spatial distinction can be perceived between Germany and Scandinavia; on the contrary, the latter seems rather to be merged into the former. The North in the early modern period was not particularly significant in Italian culture, and moral assessment in encounters with Northern people remained ambiguous. ${ }^{12}$

Before the rupture caused by the Protestant Reformation, the North represented both negative and positive values. Undoubtedly, elements such as the barbarism of the people living there, the poor hygiene, and the systematic recourse of bad food were underlined. However, according to the Late Medieval interpretations of climate theory, the Nordic peoples were also characterized by a number of positive particularities. The vision of the North and its inhabitants as 'other' and barbarian was founded on two major theories linked to each other: climate theory and the notable theory of humours. ${ }^{13}$

Climate theory was established in the early modern period largely as a result of Bodin's Six livres de la Republique (1567). Bodin drew on the thoughts of Hippocrates and Aristotle in order to explain the differences among the peoples and their customs. Hippocrates had divided the known world into three zones (hot, cold, and temperate), a tripartite that had an enduring success over time. According to Greek thought, the inhabitants of the North were by nature predestined for freedom, while the ones in the South were destined for slavery. The northerners were proud but also too wild; hence their anarchist tendencies. The inhabitants of the South, however, were smart but lazy, and easily let

12 Pastore Stocchi, 'Il mito del Nord nella letteratura dell'Umanesimo'.

${ }^{13}$ De Anna, Il mito del Nord. See also Langum, 'Cold Characters', in this volume. 
themselves be dominated by tyrants. Accordingly, it was up to the temperate zone to establish an ideal mix between these two realities.

The Renaissance humanists attributed such privilege to the Latin countries and eventually also to France. Bodin in particular tried to use the climate theory to explain the characters of the peoples and their different inclinations. ${ }^{14}$ The man from the North was brutal, wild, silent, but pure. The man from the South was led by philosophy, mathematics, and magic. He was capable of meditation and was religious, yet at the same time he was volatile, crafty, and vindictive. In the temperate zone the men were vigorous, but they were definitely less feral, a consequence of their balanced 'humours' that the inhabitants in the Latin countries could enjoy thanks to a privileged geographical position. Hence the spirit of 'civilization' of Europe (and in particular France) was born - a civilization that 'the barbarians' of the North could observe while being aware that they could never come near it. Such a civilization had to be imposed since, if left on their own, the northerners would not be able to find sufficient cohesion to pull them out of barbarism. Being too phlegmatic, they needed a guide. They were strong and vigorous, but their mental capacities were limited. The Latins, on the contrary, were of a lower stature and a less impressive bodily constitution, but their intellectual capacities were enormously superior. Moreover, the North had not produced anything that could compete on an intellectual level with the literary production of the Italian, Spanish, and, above all, French worlds. The Nordic languages were simply too full of consonants and palatals to be suitable for poetry. ${ }^{15}$

Such a view was similar to the Arabic concept of the 'barbaric'. From the ninth century onwards, Arab culture developed a climate theory with many similarities to the Aristotelian theory. The image of Northern Europe as prey to wilderness and in a primitive state started to find its way into the Mediterranean along the Islamic coasts. Arabic authors insisted that the inhabitants of Moldavia did not know the art of living in stable homes, but rather lived in the forests and systematically ate all foreigners who dared approach their world; the primitive, forest-dwelling Norwegians were characterized by the fact that their head was attached directly to their back, since they lacked a neck. They

14 Siraisi, History, Medicine, and the Traditions of Renaissance Learning, p. 58.

${ }^{15}$ See especially Borca, Luoghi, corpi, costumi; Arcangeli, Davide o Salomé?, in particular pp. 235-40; and Arcangeli, 'Fonti europee e cultura arabo-islamica'. Also important is Jones, 'The Image of the Barbarian in Medieval Europe'. For a new insight: Floyd-Wilson, English Ethnicity and Race in Early Modern Drama, in particular pp. 23-47. 
hid among the trees and carved shelters inside the trees to find refuge; the use of the sauna was interpreted as an escape from the freezing winter. ${ }^{16}$

The absence of light was a crucial element: it indicated a lack of a fundamental balance in nature and, therefore, in men. These humans became almost bestial. For example, it was not possible to trade directly with the Finns, since they could not stand the sight of other people. When someone wanted to exchange slaves or furs for swords, they could not meet them directly; instead, they left the goods in a designated place and returned to see if the Finns had left a sufficient compensation. If the exchange had not been satisfactory, the goods were returned according to the same principles. ${ }^{17}$

Over the course of the early modern period, however, the classical interpretation of climate theory began to crack, due to the new role assumed by the North in European politics and religion. ${ }^{18}$ From the seventeenth century onwards, it was no longer possible to ignore the 'civilization' of cultures in Germany and England. As count and diplomat Lorenzo Magalotti, who visited Sweden in 1668, declared in his book Relazione sulla Svezia (Report on Sweden), the Swedes were definitely gifted with a 'natural roughness. ${ }^{19}$ If left to fend for themselves, the inhabitants of this area would manifest all their limitations:

gli Svezzesi in generale sieno facili a credere, e forse più de' Tedeschi; testimonio ne può essere l'opinione che vi corre delle tante stregonerie che in quelle parti si facciano, onde a questo conto abbruciano senza discrezione uomini e donne, ed in particolare le vecchie e le più brutte. Mai si discorre d'altro che delle stregonerie delle province settentrionali, come di Norvegia, [di] Dalarne e della Lapponia. ${ }^{20}$

(The Swedes in general are naïve, and perhaps even more so than the Germans: a testimony of this may be the common view on the multitude of witchcrafts that are to be found in these parts, in which they burn men and women without discretion, and in particular the old and the ugliest ones. One never hears of other things than witchcraft from the northern provinces, such as Norway, Dalarna, and Lapland.)

16 Al-Azmeh, 'Barbarians in Arab Eyes'.

17 Al-Azmeh, 'Barbarians in Arab Eyes', pp. 11-13. For further notions of characteristics of the Finns, see de Angelo's essay in this volume.

18 This reconsideration might have been parallel to the attention payed by the scientific literature in confronting the idea of the North. For this question, which can not be further developed here, see the important contribution by Ruiu, Les Récits de voyage aux pays froids.

19 Magalotti, Relazioni di viaggio in Inghilterra, Francia e Svezia, p. 288.

${ }^{20}$ Magalotti, Relazioni di viaggio in Inghilterra, Francia e Svezia, p. 291. 
Magalotti was frustrated by the political ineptitude of many Swedes:

Oltre all'esser creduli sono gravi, sospettosi ed altieri, e senza segreto, pigri e tardi al venire alla conclusione di quello che hanno da fare. Pretendono ricompensa d'ogni minima cosa [...]. Sono irresoluti, né da loro si sente mai una risposta categorica, fra la gente eziandio con politica, trasportati dal genio di far mistero d'ogni cosa: il che arriva a tal segno che vuolci un gran negoziato a fargli risolvere a andare a desinare con alcuno, eppure è certissimo che mostrano maggior senso, che in niun'altra cosa, nel mangiare e nel bere. ${ }^{21}$

(Apart from being credulous, the Swedes are also serious, suspicious and arrogant, and without secrets; they are lazy and late to reach a conclusion in what they have to do. They claim reward for every smallest thing [...]. They are irresolute, one never hears a categorical answer from them, among the people also in politics, carried by the spirit to create a problem out of everything: it comes to a point where it takes a major negotiation to make him go and have dinner with someone, and still he demonstrates a good sense, as in no other case, when it comes to eating and drinking.)

The Swedes were also 'vain', spenders of public resources, and so on. His merciless descriptions reinforced the barbarity of a people.

But Magalotti also paints a picture of shifting colours, since in Sweden one could also find 'uomini di savio e discreto avvedimento, egualmente capaci nel negozio e nell'armi, ed insomma atti a governare' (men of sage and discreet foresight, equally capable in trade as in arms, and hence fit to rule). Their barbarity was much attenuated by the 'application to studies' symbolized by the country's university system. In this case, the 'natural inclinations' of the North were overcome thanks to the 'culture'. According to Magalotti, the image of the Swedes was about to change, as Sweden was 'una nazione assai diversa da quelle che ne la figurano le storie e le tradizioni' (a nation very different from these in stories and traditions). Before, 'non si valutava [...] di questa nazione altro che un valore spinoso e salvatico' (this nation [...] was not given any other value than a thorny and wild one), while now qualities were recognized that would never have been attributed to people living 'somewhere beyond 50 degrees'. Hence, there were Swedes who were 'polite', 'spiritual', 'learned', and 'well mannered'. A growing number of people had started to envy la lor prudenza e gli credano capaci di far col consiglio tutto o poco meno di quello che hanno saputo fare coll'armi' (their prudence, and they thought them capable of doing with counsel all or little less than they had done with weapons.). ${ }^{22}$

${ }^{21}$ Magalotti, Relazioni di viaggio in Inghilterra, Francia e Svezia, p. 295.

${ }^{22}$ Magalotti, Relazioni di viaggio in Inghilterra, Francia e Svezia, p. 296. 
Magalotti's analysis is interesting for many reasons. First, while drawing on the theory of climates, Magalotti also distances himself from it, underlining the role of culture and of acquired abilities. In other words, the civilizing role of history and the possibility to change creates an idea of possible progress. Second, Magalotti pays attention to the particular. He moves away from the assumptions of a common identity of the North by paying attention to the diversities and this gives further credence to the suggestion that cultural and political elements might have a greater impact than human nature. For example, he notes, there were huge differences between Sweden and Denmark. Magalotti tells a story to prove it:

quello che qua dicono gli Svezzesi: cioè che Dio, creando il mondo, fatta la Danimarca, stracco dalla gran fatica, ordinasse al diavolo che si scapricciasse ancor egli in fare un paese a suo modo e suo favorito, ond'egli fece la Svezia, della quale ridendosi Iddio disse che non voleva disfare il fatto ma, per ridurre le cose ad uguaglianza, si risolvè di fare egli gl'uomini alla Svezia, e che 'l diavolo facesse quelli di Danimarca. ${ }^{23}$

(this that is said here about the Swedes: that God, while creating the world, was finished with Denmark and was struck by a heavy fatigue, and ordered the Devil to create a country in his preferred way, after which the Devil created Sweden, which made God laugh and say that he didn't wish to undo this but, to balance things, he decided to create the people in Sweden, and that the devil should create those in Denmark.)

Although in the humanist tradition of northern Italy, the North was generally an indistinct gathering of territories with common climate and cultural characteristics, there were also areas in which such blurred images became more specified. Fields connected to technical and practical knowledge, rather than those connected with the literary tradition, were particularly permeated by new knowledge. In fact, from the Middle Ages onwards, missions directed towards the North Sea had occupied missionaries who could observe up close the difference between real life and life as it was depicted in classical texts. Despite this increase of information, the idea of the North continued to be based more on imagined geography than on concrete knowledge. It was as if there was a parallel North, another place, where projections and fantasies could be settled.

${ }^{23}$ Magalotti, Relazioni di viaggio in Inghilterra, Francia e Svezia, p. 321. 


\section{The Evil North and its Religious Effects}

The North in early modern Europe represented a broad variety of assumed qualities and beliefs: cold, dark, isolate, infertile, remote, out of control, warloving, barbarian, home to physically superior yet intellectually weak inhabitants, and a place for magic, witches, sorcerers, and other magical creatures and, accordingly, a natural home for heresy to thrive. ${ }^{24}$ The Reformation fitted well into this idea of the North. One of the most detailed accounts of the various kinds of magic and heresies existing in the northern parts of Europe in the sixteenth century was written by the exiled Swedish bishop Olaus Magnus, in his famous history of the Nordic peoples, Historia de gentibus septentrionalibus (1555). In Rome, escaping the Lutheran regime in his country, he urged the Catholic Church to reconvert Sweden to the old faith. Details of ancient magic and terrible monsters served to make the North exotic and heathen.

Diplomatic accounts and other archival sources from seventeenth-century Italy describing the North paint a picture of a hostile, cold, and uncivilized territory, where the question of religion (or lack thereof) is recurrent. ${ }^{25}$ When an anonymous author made an attempt to summarize the state of (Catholic) Christianity and the number of faithful in Europe in the year 1686, he described the northern countries as vast, unpopulated, partially covered with snow and ice all year round, mostly impossible to cultivate, and hence an uninhabitable territory:

Il Regno di Noruegia, e di Suetia comprendendoui l'Islanda, la Liuonia, e l'Ingria sono di una gran stenduta, ma cose spopolate per quanto si è osseruato, che quasi non si può credere. Non ui sono che Montagne inhabitabili, e perpetuamente coperte di Neue, e di giacci, et essendoui di molti Laghi, e uastità di Selue con pochissime Terre fertili, \& coltiuabili. ${ }^{26}$

(The kingdoms of Norway and Sweden including Iceland, Livonia, and Ingria, are widely extended but so scarcely populated, from what can be observed, that it is hardly impossible to believe. There is nothing else but inhabitable mountains, eternally covered in snow and ice, and there are many lakes, and vast fields with very little fertile soil possible to cultivate.)

${ }^{24}$ See also DeAngelo's essay in this volume on the heresies and witchcraft identified in Scotland as a northern place.

25 On the entire subject, see De Anna, Il mito del Nord.

26 Archivio di Stato di Venezia, Miscellanea Atti diversi Manoscritti, 82:g (no foliation), Descrittione dello Stato della religione Christiana. 
He added that there are a few Catholics in Sweden, Norway, and Denmark, but they are of such small number that it is useless to count them; the other three million souls said to live in the region were assumed to be Protestants.

Because of the Reformation, considerations related to religious affiliation, the climate, and the 'nature' of the Nordic men and women were judged morally. The 'damned lands' of the North had embraced the Reformation. The evil wind that wanted to destroy the Church and the religion continued to blow. The Jesuit Domenico Bernini was very explicit on this point in his Historia di tutte l'heresie (History of All Heresies). Historia is an important work since it constitutes the reflections of a cleric without engaging in high theological arguments, and can therefore be viewed as representative of a rather common and widespread way of seeing things. It was published for the first time in 1657 and was republished in a small number of editions up to 1723 . From the North, 'si scaricasse il fulmine sopra l'alto pinnacolo del Tempio di Dio' (one thunderbolt after the other in the pinnacle of the Temple of God) struck. ${ }^{27}$ According to this interpretation, the role of the North was not passive - it was a culture that in its roughness had provided shelter to Lutheran and Calvinist ideas. ${ }^{28}$

Tommaso Campanella very profoundly connected the source of the Reformation to the anthropological character of the northern people. The northerners, he wrote, had an undomesticable nature that could not stand restrictions. The Church of Rome had virtuously elaborated a series of prescriptions commanding 'astinenze, digiuno, castità e cose simili, che impediscono i piaceri e la buona cera' (abstinence, fasting, chastity and similar things, which prevent pleasures and the healthy appearance); the peoples of the North, however, being 'essendo veglino facili a lasciarsi trasportare dai loro affetti, non fu difficile cosa spingerli a questa libertà di vivere' (easily carried away by their affects, were easily urged to this freedom of living). ${ }^{29}$ Therefore, 'senza pensarvi' (without thinking of it), it happened that they welcomed the Reformation and the teachings of Luther and Calvin,

I quali insegnano che l'uomo non ha libertà di volere il bene e il male, ma che Iddio opera nell'uomo e l'uno e l'altro e perciò facilmente si persuadono non consistere in loro arbitrio il bere e il puttaneggiare. ${ }^{30}$

\footnotetext{
${ }^{27}$ Bernini, Historia di tutte l'heresie, II, 365.

${ }^{28}$ Bernini, Historia di tutte l'heresie, IV, 305, 563.

${ }^{29}$ Campanella, Discorso sui Paesi Bassi, p. 67.

${ }^{30}$ Campanella, Discorso sui Paesi Bassi, p. 67.
} 
(They who teach that man does not have a freedom to want the good or the bad, but that God works in man and one and the other and therefore easily were persuaded not to persist in their lust for drinking and whoring.)

The North as an indistinct idea was replaced for the first time within the Italian territories in the 1620s, thanks to Sweden's participation in the Thirty Years' War. Italy at the time was flooded by an enormous quantity of newspapers, journals, and handwritten sheets that accounted for the theatre of war and provided opportunities for readers of all levels in society to know the protagonists in the conflict. Here, religious affiliation ended up in conflict with the political sphere. ${ }^{31}$

The North provided powerful images to build on for an aspiring power such as Sweden. Academic works and debates stressed claims of being the origin of the civilized world from the Goths up to the seventeenth century, not least in Uppsala. ${ }^{32}$ At the beginning of the seventeenth century, the eschatological expectations of the Lion of Midnight, which would emerge out of the long dark season of the North, were made widespread through a circulating text attributed to the physician and alchemist Theoprastus Paracelsus. The Lion of Midnight was predicted to defeat the Eagle (the Habsburg emperor, and thus the Catholics) and lay the whole world at his feet before Christ returned. The Lion of Midnight was presented as a key character in the Apocalypse, and as such, a rewarding image to translate into contemporary politics by transforming it to the Lion of the North, the emblematic image adapted by Gustavus Adolphus in the Thirty Years' War. ${ }^{33}$

Images of the Lion of the North were picked up in Italy for political purposes. The case of Venice is instructive here. During the first half of the seventeenth century, the government of the Republic of Venice was engaged in a jurisdictional fight with the Pope. Venice was very suspicious of Rome's attempts to extend its protection not only in the religious but also in the politi-

${ }^{31}$ Infelise, Prima dei giornali.

32 Johannesson, Gotisk Renässans; Lindroth, Svensk Lärdomshistoria, pp. 235-57. See also Stefan Donecker's chapter in this volume on the North as the vagina nationum.

${ }^{33}$ Donecker, 'The Lion, the Witch and the Walrus'. Later in the seventeenth century, King Charles XI chose the Polar Star as his symbol. The Polar Star is not overwhelming or spectacular in the same way as the Sun, the well-established symbol for Charles XI's contemporary Louis XIV, but rather pale and cold. It does not change shape, as does the Ottoman crescent. However, it has one important quality: it is constant. It never moves, and it does not disappear every night, but it is reliable, stable, and unchangeable, values of utter importance for a great power in decline. 
cal sphere. Thus diplomatic contacts were extremely strained, and the Venetian government undertook a number of initiatives that marked the autonomy of the Republic in the ecclesiastical as well as in the political field. This standpoint apparently created hostility in meetings held with Rome's main ally, Spain, and was made evident in attitudes towards the North, which, in these decades, was no longer regarded as a religious enemy but rather as a political model. According to many Venetian rulers, Gustavus Adolphus incarnated the prototype of an absolute monarch, but most of all a 'total' concept of power: the Protestant countries in general appeared to have succeeded in keeping the Church and the State on separate tracks, but the State was the main actor in controlling the Church. ${ }^{34}$ It was a position that could take extreme forms: at the beginning of the seventeenth century, Nicolò Contarini, who would become doge, wrote in his Venetian Histories that even the Turks could be envied because there were no theologians among them, and the government could use religion as an instrument for social control with State and Church coinciding. The dream of an autonomous ecclesiastical government model resulted in the abandonment of the climate theory in favour of a political-religious geography in which the North could serve as example. ${ }^{35}$

It is interesting to notice the continuing fluctuation within Italian culture between exoticization of the North, with a condemnation of its costumes and inhabitants as inclined to barbarism on one hand, and the Edenic and primitivistic dimension on the other. In particular, before the Reformation a sort of 'primitivistic myth' of Nordic virtue circulated for a long time in Italian culture. According to scholar Manlio Pastore Stochhi, Italian Humanism was prone to condemn the 'sensual and dizzying weaknesses of the most sunny climates'. Although this was not the view of the majority, it was nonetheless present, and it clashed with a separate tendency to hold the Nordic people responsible for the fall of the Roman Empire and the following civil decadence. ${ }^{36}$

In this context, the diffusion of the Historia de gentibus septentrionalibus by Olaus Magnus, written in close contact with the Italian environment (and in particular the Venetian one), is strongly motivated by preoccupations of religious character. ${ }^{37}$ It encouraged a widespread notion of a North steeped with obscure, pagan, and superstitious beliefs. Olaus Magnus's book became - no

\footnotetext{
${ }^{34}$ Spini, Ricerca dei libertini.

35 Barbierato, The Inquisitor in the Hat Shop, pp. 118-19.

36 Pastore Stocchi, Il mito del Nord, pp. 50-52.

37 Olaus Magnus, Historia om de nordiska folken.
} 
matter the various intentions of the author - a sort of reservoir from which to draw a rich repertoire of beliefs that served to satisfy the primitivistic appetites of many educated elites: the success of Nordic locations in dramas and literary works in which vendetta, blood, and death formed the leitmotif shows the reach of Olaus Magnus's ideas. ${ }^{38}$

\section{The Evil Wind of the North}

Queen Christina of Sweden, daughter of Gustavus Adolphus, and regent from her father's death in 1632 to 1654 when she converted to Roman Catholicism, strategically deployed the concept of the North by connecting it to her intellectual and cultural interests. The fact that the daughter of the famous Protestant King chose to become a Catholic and set up her court in Rome obviously made playing with the North-South metaphors even more thrilling and fruitful.

The founder of several academies and the patron of the arts and sciences, Christina was noticed and mostly admired in the intellectual circles and courts of Europe. The Queen's close association with the North was ever present in her public appearances in Europe. She became referred to as the Minerva of the North, since she was the daughter of the Lion of the North (Gustavus Adolphus) and - employing metaphors from Greek mythology — she moved Parnassus (the home of the Muses) to cold Thule, transforming Stockholm into the Athens of the North. ${ }^{39}$

Ambiguous notions of Queen Christina and the North led to clashes between cultures and traditions as she travelled in southern Europe, especially with regards to non-Catholic beliefs and their northerly origins. When Pope Alexander VII prepared for Queen Christina to arrive in Rome in December 1655, he was careful with the details. Since the abdicated queen could not be immediately installed in Palazzo Farnese at the time of her arrival, she was granted a provisory apartment within the Vatican. The apartment was not in the Papal palace but in the tower called Torre dei Venti, the Tower of the Winds. The eight rooms in this astronomic observatory were decorated with frescoes depicting, among other motives, representations of the four winds. The pope inspected the apartment in person to make sure everything was in perfect order. Upon his request, the biblical motto on the northern wall, Omne malum ab Aquilone (All evil comes from the North), was hastily painted over with a

${ }^{38}$ For this point, see Selmi, 'Olao Magno nella letteratura del Cinquecento'.

${ }^{39}$ Lindroth, Svensk Lärdomshistoria, pp. 200-03. 
thick layer of paint to avoid the risk of offending the prominent guest. ${ }^{40}$ This rushed coverage and makeover of a wall was also a metaphorical act: a major change of identity was taking place, with some elements needing to be publicly eradicated while others could be usefully retained. Although the North had persistently been associated with the brave, dangerous, powerful, savage, bold, and evil, Christina's visit forced a quite literal cover-up of such evil associations.

During a stay at the court in Ferrara on her way to Rome after her abdication of the Swedish throne, Queen Christina attended a performance of the moral drama L'Oritia. The play was written by Almerico Passarelli especially for this occasion. It dramatized a romance between a nymph, Oritia, and the North Wind, Borea (Figure 13.3). ${ }^{41}$ In the second scene of the play, Borea takes on the disguise of a beautiful youth and approaches the desired nymph, saying:

\author{
Il mio rigido aspetto \\ Con più vaga riforma \\ Cangiato hò in questa forma; \\ Che resti Amor non vuole \\ Un neuoso Aquilone in faccia al Sole ${ }^{42}$
}

(My rigid face $\mid$ in a graceful way $\mid$ I have changed into this shape | Love doesn't want | a snowy Northern Wind | in front of the Sun)

The choice of this classical theme for a play in honour of the northern queen on her journey to a new life in the South is ambiguous. Is the queen supposed to be identified with the nymph fleeing from the evil and violent North, or is some of the forcefulness and enigmatic exoticness of the North to be held in her favour? In the context of this chapter, however, our main focus is on the recurrent usefulness of climate metaphors and the use as markers of opposites: in the love theme in the classical story, leading to Boreas raping Oritia, for example, the stiff and snowy Northern Wind encounters the warm sun and needs to change his appearance in order not to scare the loved one away.

The North and its wind was a source of evil and heresy. In 1687, in a work dedicated to Christina of Sweden, the Jesuit Nicolò Maria Pallavicino gave a plain example of the North as the source of heresy. In the author's opinion, the prediction 'Ab Aquilone pandetur malum' (from the north comes evil) defined very well the war between Hell and the Church, through Luther and Calvin.

\footnotetext{
${ }^{40}$ Garstein, Rome and the Counter-Reformation in Scandinavia, p. 758.

${ }^{41}$ Garstein, Rome and the Counter-Reformation in Scandinavia, pp. 753-54.

42 Passarelli, Oritia, pp. 43-44.
} 


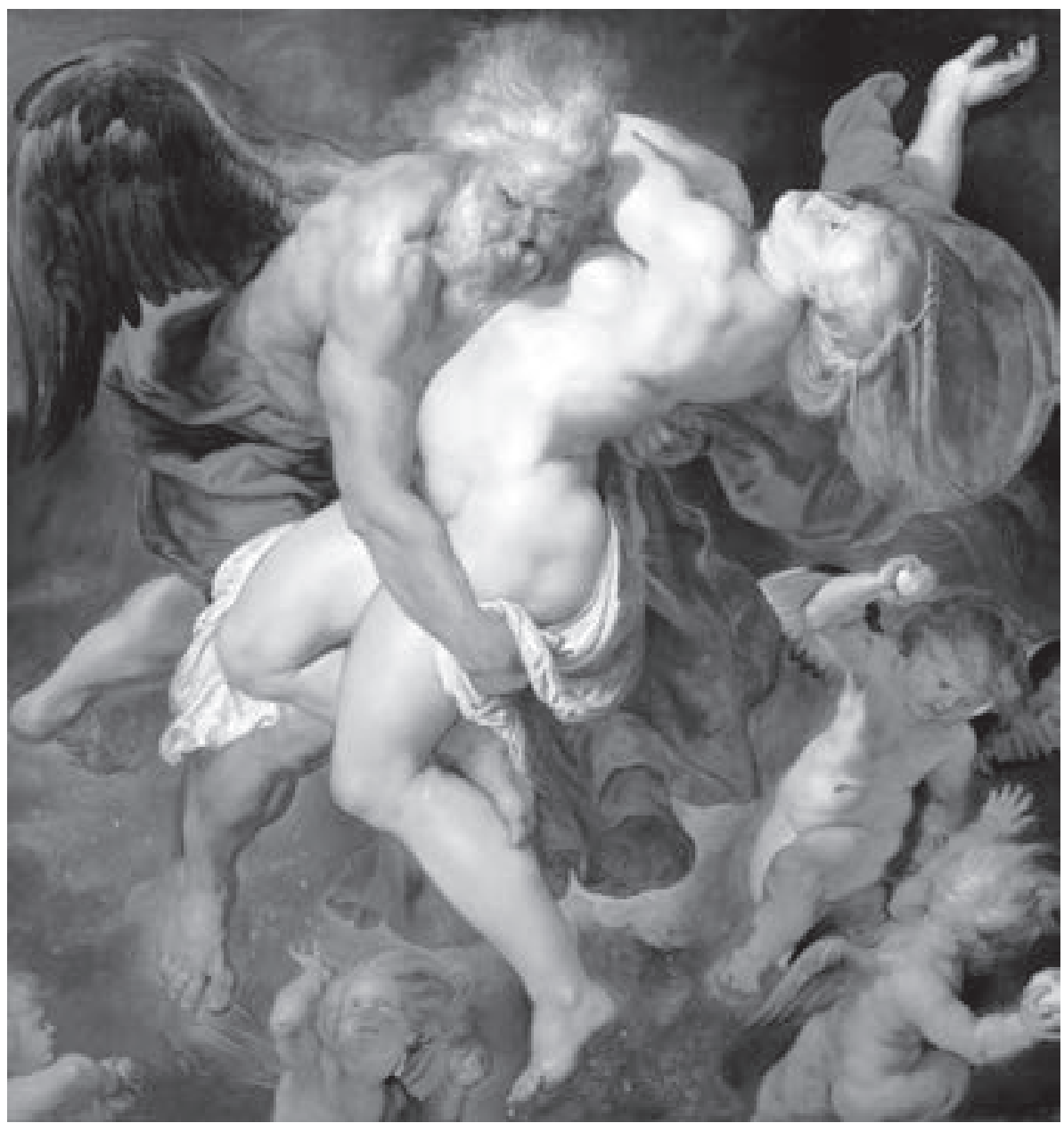

Figure 13.3: Peter Paul Rubens, Boreas abducting Oreithyia. Vienna, Akademie der bildenden Künste. 1620. Reproduced with permission from Akademie der Bildenden Künste Wien.

Moreover, in his opinion all heresies derived 'ab aquilone' (from the North), 'perché il lor principale architetto è il superbo regnatore del mitico Aquilone, cioè il Demonio' (since their principal architect is the sovereign ruler of the mythological Aquilone, namely the Devil). Citing and interpreting the letters of Saint Augustine rather liberally, Pallavicino let the North personalize the reign of Satan, where 'ne paesi Aquilonari assoldó le più feroci, e numerose Centurie di Ribelli' (in the aquilonarian countries, he engaged the most fierce and numerous centurions of rebels). Certainly, it was not the first time that 
heresy had struck the Church, but whereas previous heresies - like Arianism, Donatism, or Manichaeism - had come from the South and questioned just one aspect of doctrine, this time a heresy had come from the North that summoned all previous heresies from Hell. These poured, like rivers and streams, into the great sea of Lutheranism. Aquilone, the North, could be nothing but the house of evil. ${ }^{43}$

But the Northern Wind, as the Jesuit Luigi Albrizio preached in the midseventeenth century, was something more: 'the name of Aquilone signifies the devil'. The North was not just the house of the devil, but the devil itself. ${ }^{44}$ This was evident also in 1583, when Ippolito Caracciolo roused the crowds in a Milanese piazza by stating, 'Per Aquilone intendi tu la fede del diavolo, intendi il peccato' (by Aquilone, you mean faith in the devil, you mean sin). ${ }^{45}$ To give up the South of Grace meant turning to the North of Satan. These were the remains of a widespread topos that had featured in Italian homiletics since the Middle Ages. In 1305, Fra' Giordano had explained to the faithful gathered in Santa Maria Novella in Florence that the Northern wind is 'il Demonio che dàe seccitadi e freddura d'amore di Dio, e del prossimo' (a demon who brings dryness and coldness in the love of God and neighbour). ${ }^{46}$

Homiletics contained an element of particular importance for the spread of a negative and hostile image of the idea of the North. A true star such as Girolamo Savonarola, who roused the masses with his sermons, invoked the North Wind by repeating the famous visions by Zacharias adapted to a vast and heterogeneous audience:

$\mathrm{O}, \mathrm{O}, \mathrm{O}$, fuge de terra aquilins, Egli venne uno spirito grande a questo proheta et gridò tre volte, $\mathrm{O}, \mathrm{o}, \mathrm{o}$, fugitevi della terra di Aquilone [...]. O sacerdoti, o religiosi, o seculari, fugite dalla terra di aquiline, fate penitentia. $\mathrm{O}$ citadini, o donne, o fanciulli, fugite della terra di aquiline, venite a Christo. O grandi, o mezzani, o piccolo, fugite de terra aquilonis, fugitevi da vitii, et fate penitentia. ${ }^{47}$

(Oh, Oh, Oh, flee from the land of the northern wind, He was a great spirit and this prophet cried three time, Oh, oh, oh, flee from the land of the northern wind $[\ldots]$. Oh priests, oh religious, oh seculars, flee from the land of the northern wind,

43 Pallavicino, Difesa del pontificato romano e della Chiesa cattolica, II, 5-7.

${ }^{44}$ Albrizio, Prediche fatte nel palazzo apostolico, I, 38.

45 Caracciolo, Prediche, appresso Iacomo Antonio Somascho, p. 308.

46 Da Rivalto, Predice del beato fra' Giordano da Rivalto, p. 198.

47 Savonarola, 'Predica del mercoledì dopo la domenica di Quaresima', in Prediche deuotissime et piene de diuini mysterii. 
repent. Oh citizens, oh women, oh girls, flee from the land of the northern wind, come to Christ. Oh grand, oh medium, oh small, flee from the northern wind, flee for your life, and repent.)

The North Wind and the North represented not only physical elements, but also a wider idea. For Savonarola, the northern wind was symbolic, a moral desolation described in a crude and material language that did not fail to touch his listeners. The northern wind, 'furious and cold', was opposed to the 'nice and warm' southern wind, with the latter being signs of opulence.

But this cold wind that had blown from the North and dried out the consciences of the faithful, driving them to abandon the Church of Rome, had in fact, according to the Jesuit Tommaso Reina, increased the appreciation of the South by the Church, which had had the ability to renew itself and to become even more splendid. ${ }^{48}$ The continuing transfer from the moral to the material dimension was a common rhetorical strategy. The metaphorical use of the wind and desolation, of the rigidity and the sterility provoked by this, was bound to set off associations in the popular imagination.

Altogether, there was no doubt: 'per l'aquilone, horrido e freddo, s'intende l'inferno, che ogni cosa distrugge e consuma' (for the Northern Wind, terrible and cold, hell awaits, which destroys and consumes everything $).{ }^{49}$ It was nature's plan to demonstrate that the evil came from the North. According to the Jesuit Marcello di Lauro, evil from the North had a long history. Mentioning the barbarian peoples that had crushed the Roman Empire, he asked:

che bisogna dir di più? Di quanti emuli di Lucifero alzarono il foglio su l'Aquilone a gran fatica trovarete alcuno, a cui dir non si possa 'quomodo cecidisti de caelo Lucifer qui mane oriebaris? ? $^{50}$

(What more needs to be said? Out of all imitators of Lucifer who lifted the sheet of the northern wind, you will find it most difficult to find any, of which cannot be said 'How art thou fallen from heaven, O Lucifer, son of the morning?')

In Italy, the state of things described above lasted until the end of eighteenth century. On the one hand, the world had started expanding in an uncontrollable way. On the other, the development of cultural awareness and territorial pride such as that expressed by the Germans or the English would cause a crisis

48 Reina, Prediche quaresimali di Tomaso Reina, p. 416.

49 Inchino, Prediche sopra i quattro novissimi, pp. 292-93.

${ }^{50} \mathrm{Di}$ Lauro, Prediche per la Quaresima. The biblical reference is obviously Isaiah 14. 12. 
in a climatological and religious system. The economic and cultural development in the 'ultramontane' area would force the world to redefine itself and its geography.

The notion of the North as evil was invoked throughout the early modern period in Italy and clearly impacted North-South encounters, in particular after the Reformation. These encounters should, of course, be further explored, particularly in uncovering the presumptions and concepts of both the North and South made visible in the encounters, and the parallels and reversed conditions in Italy and Sweden at the time. We have shown that the North was characterized as evil by Italians, but how were these deeply rooted notions used more concretely in religion and politics, and how did they affect relationships and encounters? What was permitted and what was forbidden in contacts? Deterrent, moralizing, artistically inspiring, or a scapegoat for things gone bad: the evil qualities of the North through history as we have seen are multiple and complex, but perhaps most of all - they have proven useful.

\section{Works Cited}

\section{Manuscript}

Archivio di Stato di Venezia, Miscellanea, Atti diversi Manoscritti, 82:g, Descrittione dello Stato della religione Christiana cioè del numero delli Christiani, che habitano l'Europa, fatta dal Sig. N.N. 1686 (no foliation)

\section{Primary Sources}

Albrizio, Luigi, Prediche fatte nel palazzo apostolico, 2 vols (Venice: Francesco Baba, 1652) Battista Cartegni, Giovanni, Trattato de venti in quanto si appartiene al medico (Pisa: Lionardo Zeffi, 1628)

Bernini, Domenico, Historia di tutte l'heresie, 4 vols (Rome: Nella stamperia del Bernabò, 1709)

Campanella, Tommaso, Discorso sui Paesi Bassi, in Discorsi ai principi d'Italia ed altri scritti filosofici, ed. L. Firpo (Turin: UTET, 1945), pp. 65-89

Caracciolo, Ippolito, Prediche, appresso Iacomo Antonio Somascho (Venice: [n. pub.], 1600)

Di Lauro, Marcello, Prediche per la Quaresima (Venice: Baba, 1654)

Inchino, Gabriele, Prediche sopra i quattro novissimi (Venice: Domenico Farri, 1651)

Lord Lansdowne [George Granville], The British Enchanters: Or, No Magic Like Love, in The Works of the English Poets, ed. by Samuel Johnson (London: E. Cox, 1779), xxv, $267-68$ 
Olaus Magnus, Historia om de nordiska folken [Rome, 1555] (Uppsala: Michaelisgillet, 1909-51)

Pallavicino, Nicolò Maria, Difesa del pontificato romano e della Chiesa cattolica, 3 vols (Rome: Nicolò Angelo Tinaffi, 1687)

Passarelli, Almerico, Oritia, drama morale del dott. Almerico Passarelli alla Sacra Maestà di Christina regina di Suetia nel di lei passaggio. Recitato in Ferrara d'ordine del signor marchese Cornelio Bentiuogli con la musica del signor d. Andrea Mattioli e machine del signor Carlo Paseti (Ferrara: Franc. Suzzi, 1655)

Petronio, Alessandro, Delli Romani et di conservar la sanità (Rome: Domenico Basa, 1592)

Reina, Tommaso, Prediche quaresimali di Tomaso Reina milanese della Compagnia di Giesu (Rome: Eredi di Francesco Corbelletti, 1649)

Ripa, Cesare, Iconologia (Rome: [n. pub.], 1603)

Savonarola, Girolamo, Prediche deuotissime et piene de diuini mysterii del venerando et sacro theologo frate Hieronymo Sauonarola da Ferrara. Defensione del predetto contra li calumniatori, Giovanni Mazzocchi (Ferrara: [n. pub.], 1513)

Shakespeare, William, The Jew of Venice. A comedy. Written originaly by Mr. Wm. Shakespear. Now altered \& very much improved, by the Hon. M. Granville (London: [n. pub.], 1732)

Zacchia, Paolo, Quaestiones medico legales, qui continetur consilia et responsa (Nuremberg: Johannis Georgii Lochneri, 1726)

\section{Secondary Works}

Al-Azmeh, Aziz, 'Barbarians in Arab Eyes', Past and Present, 134 (1992), 3-18

Arcangeli, Alessandro, Davide o Salomè? Il dibattito europeo sulla danza nella prima età moderna (Rome: Viella, 2000)

—-, 'Fonti europee e cultura arabo-islamica di fronte ai balli africani: missionari, viaggiatori, trattatisti', in Per Adriano Prosperi, II: L'Europa divisa e i nuovi mondi, ed. Massimo Donattini, Guiseppe Marcocci, and Stefania Pastore (Pisa: Edizioni della Normale, 2011), pp. 241-52

Barbierato, Federico, The Inquisitor in the Hat Shop: Inquisition, Forbidden Books and Unbelief in Early Modern Venice (Farnham: Ashgate, 2012)

Beller, Manfred, and Joep Leerssen, eds, Imagology: The Cultural Construction and Literary Representation of National Characters. A Critical Survey (Amsterdam: Rodopi, 2007)

Borca, Federico, Luoghi, corpi, costumi: determinismo ambientale ed etnografia antica (Rome: Edizioni di Storia e Letteratura, 2003)

Da Rivalto, Giordano, Predice del beato fra' Giordano da Rivalto dell'ordine dei predicatori recitate in Firenze dal 1303 al 1306 (Florence: Magheri, 1831)

De Anna, Gino, Il mito del Nord: tradizioni classiche e medievali (Naples: Liguori, 1994)

Donecker, Stefan, 'The Lion, the Witch and the Walrus: Images of the Sorcerous North in the 16th and 17th Centuries', TRANS Internet-Zeitschrift für Kulturwissenschaften, 17 (2010) <http://www.inst.at/trans/17Nr/4-5/4-5_donecker.htm> 
Fjågesund, Peter, The Dream of the North: A Cultural History to 1920 (Amsterdam: Rodopi, 2014)

Floyd-Wilson, Mary, English Ethnicity and Race in Early Modern Drama (Cambridge: Cambridge University Press, 2006)

Garstein, Oskar, Rome and the Counter-Reformation in Scandinavia, IV: The Age of Gustavus Adolphus and Queen Christina of Sweden, 1622-1656 (London: Brill, 1992)

Infelise, Mario, Prima dei giornali: alle origini della pubblica opinion (Rome-Bari: Laterza, 2005)

Johannesson, Kurt, Gotisk Renässans (Stockholm: Almqvist \& Wiksell, 1982)

Jones, W. R., 'The Image of the Barbarian in Medieval Europe', in Medieval Ethnographies: European Perception of the World Beyond, ed. by Joan-Pau Rubiés (Farnham: Ashgate, 2009), pp. 347-78

Klinge, Matti, 'Aspects of the Nordic Self', Daedalus, 113 (1984), 257-77

Lindroth, Sten, Svensk Lärdomshistoria: Stormaktstiden (Stockholm: Norstedt, 1989)

Magalotti, Lorenzo, Relazioni di viaggio in Inghilterra, Francia e Svezia (Bari: Laterza, 1968)

Pastore Stocchi, Manlio, 'Il mito del Nord nella letteratura dell'Umanesimo', in Il mito e la rappresentazione del Nord nella tradizione letteraria (Rome: Salerno editrice, 2008), pp. 35-56

Prosperi, Adriano, Giustizia bendata: percorsi storici di un'immagine (Turin: Einaudi, 2008)

Ruiu, Adina, Les Récits de voyage aux pays froids au XVII siècle: de l'expérience du voyageur à l'expérimentation scientifique (Montréal: Imaginaire Nord, 2007)

Selmi, Elisabetta, 'Olao Magno nella letteratura del Cinquecento', in Il mito e la rappresentazione del Nord nella tradizione letteraria (Rome: Salerno editrice, 2008), pp. 69-103

Siraisi, Nancy G., History, Medicine, and the Traditions of Renaissance Learning (Ann Arbor: University of Michigan Press, 2007)

Spini, Giorgio, Ricerca dei libertini: la teoria dell'impostura delle religioni nel Seicento italiano (Florence: La Nuova Italia, 1983) 